\title{
The Legal Academic of Max Weber's Tragic Modernity
}

\section{Minkkinen, Panu}

2010

Minkkinen , P 2010 , ' The Legal Academic of Max Weber's Tragic Modernity ' , Social \& Legal Studies, vol. 19 , no. 2 , pp. 165-182 . https://doi.org/10.1177/0964663909358347

http://hdl.handle.net/10138/29412

https://doi.org/10.1177/0964663909358347

submittedVersion

Downloaded from Helda, University of Helsinki institutional repository.

This is an electronic reprint of the original article.

This reprint may differ from the original in pagination and typographic detail.

Please cite the original version. 


\title{
The Legal Academic of Max Weber's Tragic Modernity
}

\author{
Panu Minkkinen \\ School of Law \\ University of Leicester
}

\section{J uridical anti-intellectualism}

In George Ruggle's well-known comedy Ignoramus from 1615, a college recorder and common lawyer named Ambidexter Ignoramus is set against the humanistic ideals of the university environment in which the play was written and performed as well as set. Ignoramus is barely semi-literate in a hybrid of bastardised French and Low Latin that made up the legal jargon of his time, and his character is ridiculed for the lack of cultivation that epitomises the uneducated professional. Ignoramus, for his part, openly resents the academic refinement that he lacks: "universitants", as he calls his aspiring academic lawyers, will allegedly never make good clerks. "Logica? Quae villa, quod burgum est Logica?" (Ruggle 1787: 47 [I: iii]), he ripostes to Musaeus, an apprentice who defensively advocates his own university schooling in logic. For Ignoramus, an art that is liberal (artium liberalium) apparently only counsels in imprudent squandering, and only harlots can be the love objects of Musaeus's self-professed amor philosophiae. Ignoramus's responses are seemingly not rhetorical because his poor command of Latin sets limits to his use of figurative tropes (further on Ignoramus and the law, see Tucker 1977). 
But perhaps it would not be too farfetched to claim that the comedic roles have been reversed since Ruggle's J acobean times. In an article specifically addressed to a North American readership, Neil Duxbury paints a grim picture about the sorry state of English jurisprudence during the 120 years or so that separate J ohn Austin from H.L.A. Hart (Duxbury 2005). Duxbury's rich and well-researched account provides an alarmingly familiar narrative about how jurisprudence was consistently discredited and ridiculed by English law schools and academic lawyers during that period. By framing the historical narrative around two prominent names evidently not much worth mentioning took place between Austin and Hart - the reader is led to believe that, as a discipline, English jurisprudence has always required the shoulders of giants, that without such giants the institutional standing of jurisprudence has been at best weak.

During the period that Duxbury deals with - extending roughly from the early 19th century to the aftermath of World War II - academic law on the continent, by way of contrast, developed in huge leaps. The doctrines that had been elaborated by Friedrich Carl von Savigny (1779-1861) and the Historical School were first being methodically formalised by Pandectist constructivists such as Georg Friedrich Puchta (1798-1846) and Bernhard Windscheid (1817-1892) and later consolidated into the rigour of a properly scientific approach to law by Rudolf von J hering (1818-1892) and his followers (see e.g. Wieacker 1995; Reimann 1990). ${ }^{1}$ This development, undoubtedly representing one of the most important periods in the history of continental law, provided the scholarly foundation on which the likes of Max Weber (1864-1920) and Hans Kelsen (1881-1973) would subsequently build contemporary sociology of law and legal positivism respectively. The

\footnotetext{
${ }^{1}$ Chris Thornhill (Thornhill 2007) provides an excellent overview of the overall political and philosophical developments during the period.
} 
codification of the German civil code (Bürgerliche Gesetzbuch, BGB) that entered into force after two decades of preparatory work on J anuary 1 , 1900, represents the socio-political culmination of this period. ${ }^{2}$

There is no reason to doubt the accuracy of Duxbury's historical narrative about England apart from its suspicious seamlessness; no real exception manages to break through the chilling regularity of disdain. For our purposes in this essay, it is, however, sufficient to flesh out and to further expand on two parallel observations.

In Duxbury's account, a key factor explaining the discredit that jurisprudence apparently suffered from amongst lawyers of that period was the close affiliation between legal academia and the practice. Practitioners often made up a large part of the law school's teaching staff, and from the practitioner's point of view, jurisprudence represented a detached approach that was next to impossible to apply in the lawyer's everyday work. Even the institutional framework of the law school in general was geared to service the vocational needs of the practice. Because jurisprudence did not offer clear solutions to practical problems, it was regarded as largely superfluous and even as unnecessary distraction from the essential. This view was especially evident in law schools of the socalled newer universities that understood their role primarily as providers of vocational training mainly for "articled" apprentices who were already practising their trade under the supervision of mentoring solicitors.

\footnotetext{
2 Although the historical sketch of the "continent" provided here is exclusively German, similar developments took place in other European countries at around the same time.
} 
The isolationist self-perception of law schools as providers of vocational training also engendered an academic response. The universities had no real interest in supporting law's non-existent aspirations to become a proper academic discipline, and the development of jurisprudence, that is, of the one subject in the law school's curriculum that colleagues in other disciplines might have been ready to recognise as genuinely "academic", was largely left to the initiative of individual non-lawyers like Hart. So while the vocational law school distanced itself from the academic environment into which it had been placed, the university responded with corresponding misgivings about the scholarly merits of the discipline seemingly obsessed with its vocational obligations and professional affiliations.

Highlighting these observations, we can relatively safely infer two generalisations from Duxbury's account without doing too much violence to his original historically contextualised narrative.

Firstly, Duxbury's claims about English jurisprudence as a discipline apply more generally to law as it is "practised" in English law schools. The fate of jurisprudence in England reflects well the anti-intellectual framework within which a particular mode of "Anglo-Saxon" legal thinking has evolved even if the institutional status of jurisprudence itself may have improved since Hart's days. J uridical anti-intellectualism favours the textbook and the legal manual over the research monograph, instruction and skills over education and edification. And even in its properly academic guises, it will steer clear from what it considers to be unproductive self-reflection and harbour the kind of technical interest of 
knowledge that the French sociologist of law Henri Lévy-Bruhl somewhat uncritically hailed as juristique (see Lévy-Bruhl 1950). ${ }^{3}$

Secondly, even though the source material of Duxbury's research is historically determined, many of his claims about jurisprudence between Austin and Hart resemble curiously the way in which law is understood as the defining element of today's English law school. The distrust of jurisprudence and other non-practical approaches to law is just as detectable today as it was a hundred years ago to which the continuous tension between an academically determined "liberal legal education" and the demands of "vocational preparation" bears witness. J urisprudence, often pushed into the ghetto of the curriculum's optional choices, is seen as just that: it is radically "optional", apparently having only a marginal relation to the professionalism of the practitioner.

Drawing on these generalisations, the aims of this essay are twofold. It will first focus on the peculiarities and historical origins of an "Anglo-Saxon" legal thinking as one of two ideal types that Max Weber develops in his sociology of law. A key factor in understanding the difference between the continental and Anglo-Saxon legal thinking is the educational

${ }^{3} \mathrm{~J}$ uridical anti-intellectualism is, of course, not a uniquely English phenomenon. In many continental legal cultures, it began as an antimetaphysical and anti-formalist critique of German Pandecticism often inspired by the socialist politics of the Freirechtsschule (see e.g. Kantorowicz 1906). But in, for example, the Nordic countries, the critique of formalism subsequently ended up as a watered-down variant of legal realism with all the rhetorical venom of an Axel Hägerström but none of the intellectual rigour of an Alf Ross or, in other words, the "worst of both worlds". 
environment in which the legal rationalities representing the ideal types were first developed and subsequently disseminated in education. However, this essay will focus less on the educational element itself but will instead shed light on the role of the legal academic as a social actor involved in the process. Moreover, in trying to argue for the centrality of a formal legal rationality in the development of modern capitalism, Weber must also acknowledge a contradiction. English law namely never aspired to such a formal rationality even though the country's socio-economic development was otherwise comparable. This discrepancy is often referred to as Weber's "England problem".

After the Anglo-Saxon ideal type has been contrasted with its continental counterpart, a tentative attempt will be made to outline an academic approach to law that is properly at home in the university. The provisional claim of this essay is that the building blocks of such an approach can already be found by radicalising the theoretical premises of the Geisteswissenschaften, that is, of the social sciences and the humanities including law that were once thought to stand in radical opposition to the natural sciences. By trying to respond to short-term instrumentalist demands that concern law understood as a social institution - the law is expected to deliver feasible solutions to practical problems - the academic discipline of law has gradually drifted further away from the hermeneutical core of the interpretative disciplines that it was once a part of. The conflation of the social institution and the academic discipline into one undifferentiated "law" is one of the key factors contributing to the university jurist's self-induced isolation in her academic environment. The essay will attempt to revitalise and radicalise the idea of law as a human science, and it is Weber's problem with England that gives an early clue as to how to proceed. 


\section{Weber's "England problem"}

In his essay "Politics as a Vocation", Weber outlines a historical typology of the "professional politician", that is, the political official employed by the Prince in his incessant struggles against the rising power of the estates. As in many of Weber's typologies, it is difficult to say for sure whether the succession of ideal types is intended to portray a gradual progression into mature European capitalism, but the evolutionary undertow is certainly audible. As his fifth and final ideal type of the professional politician, Weber names the university- trained jurist. Weber claims that only the unique rationality characteristic of the jurist could enable the development of both the sovereign state and party politics as the management of collective interests (Weber 1988: 522-523).

For Weber, it is, then, not so much a question about the possible political alliances that either the Prince or the estates may have forged with their legal lackeys. The historical development of the modern state and its unique administrative and bureaucratic infrastructure has more to do with the university-based education of jurists and, further, with the formal rationality that the universities provided in their training. This rationality was conceptualised around the structural architecture of Roman law as developed by the constructivist Pandectists and enhanced with secularised doctrines from natural and canon law.

But here, just as in his sociology of law in general, Weber must himself acknowledge what is commonly known as his "England problem". The important role of jurists in the development of continental European societies was largely due to the education that they received at university, but England managed to develop along very similar historical lines even though the training of lawyers was arranged in a very different way. The difference has both substantial and institutional dimensions, but certainly 
one of the decisive factors was the different emphasis given to Roman law on the continent and in England respectively:

The tremendous after-effect of Roman law, as transformed by the late Roman bureaucratic state, stands out in nothing more clearly than the fact that everywhere the revolution of political management in the direction of the evolving rational state has been borne by trained jurists. This also occurred in England, although there the great national guilds of jurists hindered the reception of Roman law (Weber 1988: 522).

Roman law may have always been studied by English scholars as an historical phenomenon, but legal historians and comparatists generally agree that it was never "received" in England in the same way as it was on the continent. So if the foundation of the rationality required for the development of the modern state was missing in England - that is, a university education based on Roman law - how could England's social and economic development be so similar? Weber also claims that despite the later introduction of "scientific" training in legal education in England - Weber is, no doubt, referring to the reforms that followed the critical 1846 report of the Select Committee on Legal Education - modern AngloSaxon law remains an empirical skill where the charismatic nature of adjudication is important in relation to the hierarchical status of the courts and even to the personal authority of the judges. This particular aspect relating to the authority of the courts leads Weber to associate the common law with ancient oracles:

...the role that the decision plays as the indispensible and specific form in which the common law comes to flesh corresponds to the role of the oracle in ancient law: "What was hitherto uncertain (i.e. the existence of a principle of law) has now (i.e. through the 
decision) become a permanent rule." Only a decision that is blatantly "absurd" or "contrary to a legitimate command" lacks charismatic quality and can safely be disregarded. The absence of rational grounds is the only thing that distinguishes the oracle from the English precedent (Weber 1947b: 407).

The decision of the common law is, then, dependent on a charismatic form of authority that Weber elsewhere mostly associates with either historically redundant religious societies or with dictatorships founded on a cult of personality. And because charismatic authority is intrinsically immune to external regulation, Weber considers it to be fundamentally irrational even if the English courts are obliged to provide rationalising grounds for their decisions. Furthermore, charismatic authority is an unstable and exceptional form of domination that tends to quickly stabilise itself by settling into the routines of the everyday, and as such, it becomes institutionalised often merging with traditional authority (Weber 1947b: 758-763) as the case of the common law would seem to indicate.

So despite the regularities in the socio-political and economical development of the various European countries, Weber must conclude that in English law "the degree of the rationality of law is essentially lower, and it is also of a different type than the rationality of continental European law" (Weber 1947b: 510). Not only is the rationality of English law qualitatively different, but there is also quantitatively less of it. From this one could, perhaps, tentatively conclude that, in Weber's own scheme of the categories of legal rationality (Weber 1947b: 395-397; see also Trubek 1972: 727-731), English law is essentially a substantively irrational form of legal thinking. It is irrational to the extent that it is casuistic rather than general, and it is substantive in so far as its casuistry is open to non-legal considerations such as religious, moral, political and even emotional arguments or, in short, "purposive" arguments. 
However, many commentators hold that Weber cannot resolve his "England problem" in a satisfactory way. David Trubek, to take one distinguished Weber scholar from the area of law, attributes the discrepancy to a clash between Weber's commitment to accurate historical description and his aspirations for theoretical consistency. So rather than imposing the deviating case of England into his general theoretical framework, Weber prefers to leave the issue ambiguous (Trubek 1972: 746-748). Sally Ewing, for her part, attempts to resolve the "England problem" by making a distinction between Weber's research into the formal characteristics of law and his analysis of its sociological rationality. Ewing namely claims that in the latter sense the common law is no less able to promote the development of capitalism than formally rational civil law (Ewing 1987: 497-502). Be what may, Weber does insist on some type of causality between the formal legal rationality so essential for the development of modern capitalism and the university-based education of jurists. So how was the training of "substantively irrational" Anglo-Saxon lawyers organised as compared to their "formally rational" continental counterparts? And what was the role of Roman law in this difference?

In discussing the relatively weak influence that Roman law had on the laws of England, T.F.T. Plucknett first notes that the Anglo-Saxon migrations in the 4th and 5th centuries all but wiped out the old tradition of Roman law. But even as an intellectual framework, the possible uses of Roman law in England would have been limited. On the continent, it served as a comparative standard with which the academically-minded jurists that were in allegiance to the crown were able to conceptually unify a variety of local customs. "Romanising" these customs enabled the king to better administer the plurality of his extended realm. But in early medieval England, there were only three main customs - Wessex, Mercia and Danelaw - that were relatively easy to administer anyway. Moreover, the 
common law was introduced soon after, and its rationale was completely different:

The imposition of the common law was not the work of jurists with legal dogmas to apply, but of administrators who disposed of writs and procedures for the king's profit. This system did not attempt to unify, or to reform, the local customs; it simply ignored them (Plucknett 1939: 48).

The judges that worked for the king by implementing the common law came from the ranks of civil servants and would not usually have a university education in Roman or canon law. Later the judiciary was completely laicised and separated from the clergy. Independence also brought about huge financial rewards, and so this new wealthy class of juridical administrators drifted even further away from the universities where the clergy had traditionally received its legal education. And finally, Plucknett concludes, when the training of common lawyers was gradually assigned to the Inns of Court starting from the beginning of the 14th century, the English lawyer's isolation from academia was complete:

The English legal profession was isolated, insular, small, and very homogeneous. All the important business came to Westminster where bench and bar formed one club of experts who could settle questions with equal ease in court or at supper. ... But this small group was also ambitious and powerful. It dominated parliament; when prerogative courts arose, it was still common lawyers who practised before the chancery and star chamber. They seem to have guessed the danger that new courts might import foreign learning, and deliberately organized a counter-attack. Civilians had, in fact, obtained a footing in the court of requests, admiralty, and in the post-reformation ecclesiastical courts, but the common 
lawyers succeeded in abolishing the first, and in reducing the others to impotence (Plucknett 1939: 50).

Roman law was regarded as an applicable form of law only by the Oxbridge educated advocates of the Doctors' Commons, a society of civilian lawyers practicing mainly in the ecclesiastical courts (see e.g. Baker 2002). The society, famously ridiculed by Charles Dickens in Sketches by Boz (see Dickens 1837: 175-190), was dissolved shortly after the Court of Probate Act 1857 rid the civilians of their practicing prerogatives. Indeed, in his history of English law, Frederic Maitland claims that an initial medieval influence of Roman law gradually withered away because it could not be applied in English courts by English lawyers:

As to Roman law, it led to nothing. For a while in their enthusiasm men might be content to study for its own sake this record of human wisdom, of almost superhuman wisdom, so it must have seemed to them. But it soon became plain that in England there would be no court administering Roman law, unless it were the court of a learned university (Pollock - Maitland 1898: 122).

J ust like Plucknett, Maitland here juxtaposes law as it was practised by the common lawyer with a "learned university" that was more receptive to the external influences of Roman law. And the Inns of Court with their own educational functions played a decisive role in warding these influences off. In the pressures of humanistic Renaissance ideals and the general reception of Roman law on the continent, the Inns of Court as educational institutions and "schools of living law" managed to secure a "gothic revival" of medieval English law:

No English institutions are more distinctively English than the Inns of Court; of none is the origin more obscure. ... Unchartered, 
unprivileged, unendowed, without remembered founders, these groups of lawyers formed themselves and in course of time evolved a scheme of legal education: an academic scheme of the medieval sort, oral and disputatious. For good and ill that was a big achievement: a big achievement in the history of some undiscovered continents. We may well doubt whether aught else could have saved English law in the age of the Renaissance (Maitland 1901: 26-27).

Weber presents this same historical narrative in a slightly different way. He understands legal education mainly as a way of conveying what he calls "legal thinking", that is, a body of professional knowledge (Weber 1947b: 456-467). The differences in legal thinking on the continent and in England result mainly from two parallel historical influences: the political status of the professional bodies on the one hand, and the development of legal doctrine as a response to social needs on the other. Weber first makes the basic distinction between what he calls an empirical knowledge of law handed down by the practitioners themselves and a theoretical or rational type of knowledge developed in and provided by the universities. To further highlight his own preferences - or even prejudices, as some might claim - Weber associates the former approach with the artisan crafts (handwerksmässig) while reserving the epithet "scientific" (wissenschaftlich) for the latter. We start off, then, with a basic distinction between "law as craft" typical of Anglo-Saxon law and continental "law as science".

Weber claims that the Anglo-Saxon "law as craft" approach was able to develop only because of the powerful guilds that the legal profession had organised into. The Inns of Court were able to protect their financially motivated monopoly over legal training through pupilages, apprenticeships and lecturing in both case law and court etiquette by 
warding off the universities and their Pandectist interests. The practical training provided by the Inns favoured an approach that was based on precedent and analogy, and such a focus further prevented the accumulation of legal material into any systematic unity. Weber concludes:

The aim of the legal practice itself was not to develop a rational system but instead to create practically exploitable schemata of contracts and claims that addressed the typically recurring singular needs of the interested parties (Weber 1947b: 457).

Weber notes a further consequence that arises from this "cautelary jurisprudence". The concepts that Anglo-Saxon law formulated were always oriented towards tangible and concrete facts that were familiar from the everyday experiences of the practitioner and were, in that sense, also formal. But their interrelations were restricted to unambiguous external characteristics and expanded on through previously recorded ways:

These were not, then, general concepts that could be abstracted from descriptions, whose meaning could be logically constructed, formulated through generalisation and subsumption and syllogistically applied to norms. The purely empirical concerns of the legal practice and of legal doctrine infers one singular proposition from another in order to be able to deduct individual judgements from them but does not pursue a general proposition (Weber 1947b: 457).

Wilfrid Prest expresses this same trait of the common law, "a formless, confused jumble of undigested particulars, successfully resisting all efforts at simplification or systematic statement", in the following way: 
It was a truism of both practising common lawyers and text book writers that the common law was rationally grounded upon various well-known fundamentals. By this they did not mean that its detailed propositions could be deduced from certain basic premises, nor that it was a neat and symmetrical body of knowledge. The reason of the law was in fact a mystique, a trade secret, which could only be comprehended by those who had diligently applied themselves to its subtleties for many years (Prest 1967: 31).

Weber has, then, developed two ideal types of legal thinking. On the one hand, we have a scientifically motivated thinking that is based on a systematised framework of abstract legal concepts and propositions and their logical interrelations as represented by continental law. On the other hand, we have a "crafty" type of thinking allegedly typical of Anglo-Saxon law that draws its material from the individual successes of the practitioner and attempts to consolidate its findings so that they can be further exploited through repetition by other practitioners. Weber's ideal types are, of course, just that. They are reductionist explanations of how a hypothetical social actor might understand her own action, but they do not necessarily appear as such in the real world.

But who are the social actors behind Weber's ideal types?

In relation to his preferred continental variant of Rechtsdenken, Weber usually talks about "jurists" as a monolithic mass of professional social actors. But the social actor constructing and disseminating legal thinking in a university environment must be quite different from the actor who translates the formal rationality she has been instructed in at university into working bureaucratic practices. There is, then, a difference between the instructor and the instructed, between the university jurist and the 
practitioner educated at university. The seminal publications of university jurists from Weber's own time that laid down the foundations for this formal rationality were mostly put together from lecture notes. But it is plain that, for example, von J hering's Geist des römischen Rechts (von J hering 1852) could never have been intended as a practical manual for future lawyers. It did not have any immediate relation to the vocational concerns of the practitioner who, while at university, neither requested nor received tangible tools for her everyday work.

In her task of reformulating the material of law within a rational and scientific framework, the closest associates of Weber's university jurist, the "legal academic", were not legal practitioners but her colleagues in academia irrespective of their disciplinary orientation: theologians, historians, social theorists, economists, humanists, linguists, and so on. Even Weber's own multifaceted academic profile as jurist, economist, historian and sociologist bears witness to this. By way of contrast, today's "academic lawyer" is mostly isolated from the rest of academia in her obstinate and intellectually barren affiliation with the practice and her implied commitment to seek practicable solutions for courts and practitioners. Unable to differentiate between law the institution and law the discipline, she assumes by default the position of the legal practitioner dedicating her academic work to providing guidance and tools for good lawyering.

Furthermore, the epistemological template under which Weber's university jurist conducted her research was devised for the human sciences in general covering both the humanities and the theoretical social sciences, whereas in today's academic debate claims are made for the doctrinal uniqueness of law and its subsequent autonomy in relation to other disciplines. And it is often law's affiliation with the practice that is said to account for this uniqueness. 


\section{The validity of the code}

The history of the common law is often wrapped into a heroic narrative in which the home-grown legal culture successfully wards off threatening alien influences. To a certain extent this is, no doubt, very true. But we can also reframe the narrative into an internal conflict between the two social actors: the university jurist and the practitioner or, as one could rephrase these in the contemporary university environment, the legal academic and the academic lawyer. The former represents Weber's notion of the university trained jurist, the humanist lawyer whose main contribution to modern bureaucratic practices has been the scholarly systematisation of normative data. The latter, for her part, remains a thematic variation of the practising lawyer who, even in her academic activities, remains constrained by the practical concerns of mundane lawyering. And in this internal conflict, it is the latter that currently has the upper hand.

In making the argument for the academic lawyer, reference is often made to the legal academic's alienation from the "real world" of the law that the academic lawyer allegedly has privileged access to through her affiliation with the practice. When in 1883 Albert Dicey asked in his inaugural lecture whether English law could be taught at university in the first place, his affirmative response was meant to provocatively address the general mistrust of academia that the legal community harboured. Dicey summarises the advantages of a non-academic vocational training in the following way:

The merits, in short, of the present system may be all summed up in the one word "reality". It brings a student in contact with the real actual business, and fosters in him qualities which cannot be produced by any theoretical teaching, however excellent. Readiness, technical skill, sound judgment, the power of disentangling from a mass of bewildering details the essential 
features of a complicated case, the habit of applying to the actual affairs of men the well-established rules of law, are qualities to be acquired, in so far as they are not the gifts of nature, by practice, and by practice alone (Dicey 1883: 8).

Later Dicey resolves his dichotomy by reducing the university jurist to little more than the practitioner's sidekick, and so he can comfortably conclude that the contradiction between a practical vocational training and a "theoretical" university education is merely apparent. With this move, the university jurist as academic lawyer is hailed as the practitioner's intellectual accomplice leaving the legal academic, estranged from the "reality" of law, to tinker with the minutiae of her formal propositions. The move is reminiscent of the claims that American legal realists would later make about "law in action" or "living law" in their criticisms of formalist approaches to law.

But the continental legal academic exercises her socio-political kudos in slightly different ways than her Anglo-Saxon counterpart. A first avenue of influence is related to the specific political responsibilities that the academic's professional life includes. Legal academics are often heard as experts in governmental bodies such as law commissions and legislative committees, and through their expertise, academics often have a tangible - albeit often anonymous - influence on the drafting of legislative initiatives. The expertise of the legal academic is not limited to mere legal technicalities but often covers even the most fundamental principles that inform the initiative in question. Although this type of socio-political influence is not altogether absent in the Anglo-Saxon tradition, it is less significant and limited to a very small elite.

The second and more significant way in which the continental legal academic practices her socio-political standing is through what can be 
called codificatory temperance. In continental law drafting, individual legislative initiatives that are collected together under a code are structured into the codificatory framework with the help of a logic, real or supposed, that precedes the act of legislation. In, for example, the great European civil law codifications - primarily the French Code civil of 1804 and the German BGB of 1900 - the preceding codificatory framework was heavily influenced by the structure and logic of the Roman ius civile as it had been developed by the Pandectists and other legal scholars in the universities. The legal academic's codificatory framework provided the structural preconditions of the codes. Once legislated into valid law, the codificatory framework itself acquires a validity of its own that often outlives the individual reforms that the substantive law must endure. So a subsequent change in the law will, for example, have to comply with the overall logical structure of the code that was originally provided by the legal academic. The validity of the codificatory framework is further strengthened by it being perceived rather as a logical precondition for the use of legislative powers than the academic's politically motivated attempt to influence government. The legislator will, then, be compelled to temper its powers in such a way that the logical consistency of the codificatory framework is respected in subsequent legislation.

The continental doctrine of legal sources extends the validity of the codificatory framework into the courtroom. According to the doctrineitself developed by legal academics - the sources of law that an adjudicator uses in making her decision are divided into compulsory sources such as statutory law and precedent, and admissible sources such as, for example, the legislator's travaux préparatoires. In many continental jurisdictions, legal doctrine is itself regarded as an admissible source of law if primary compulsory sources fail to provide unequivocal guidance. As an analytical presentation of enacted law, legal doctrine is likely to reinforce the validity of the codificatory framework that is already present in the primary 
sources applied. Doctrine provides interpretative recommendations by fleshing out interdependencies between individual norms in such a way that the adjudicator in doubt may draw on the binding force of the overall structure of the code. Again the authority of legal doctrine is seen to stem rather from its logical qualities than from any political motives, but the opinions of the courts seldom make overt references to academic literature. Unlike the continental adjudicator, the English judge can seldom be seen to structure her opinions on any academically recognisable pattern. The few explicit references to academic literature are sometimes even coupled with a reservation about the general authority of doctrine in legal decision making. 4

The socio-political implications of all this for the continental legal academic are far from unambiguous. On the one hand, the codificatory framework can well be interpreted as an expression of the fundamentally conservative nature of doctrinal law: it imposes formal and "logical" restrictions hampering social reform, it can be said to serve the interests of the established power elites, and so on. An illustrative example of this would be the reservations that many jurisdictions may have had against limitations to free contracting such as the introduction of unfair contract terms or legal measures for consumer protection. On the other hand, it has also served what can clearly be perceived to be progressive ends. On one level, formal and logical restraints can, if not prevent, at least hinder

\footnotetext{
4 In R v. G and Another ([2004] 1A.C. 1034, 1055-1056), Lord Bingham claims that a decision "is not, of course, to be overruled or departed from simply because it meets with disfavour in the learned journals. But a decision which attracts reasoned and outspoken criticism by the leading scholars of the day, respected as authorities in the field, must command attention".
} 
draconic abuses of state powers in, for example, the area of criminal law. But it can also contribute towards progressive ends through mechanisms resembling what Duncan Kennedy calls "formalised substantive rationality" (Kennedy 2004: 1071-1076). Once new provisions such as unfair contract terms or provisions for consumer protection have been legislated into the code, the revised codificatory framework will also allow for similar reforms in other parts of the law as well. In other words, once one element of welfare state legislation has been introduced, the revised framework will facilitate similar changes in other areas of substantive law.

But overall and historically speaking, continental doctrinal law has always included within itself a formalised social-democratic ethos of solidarity that has enhanced the realisation of the Northern European welfare state. In the process of formalisation, the ethos of solidarity has, of course, been "dehumanised" in much a similar way as the Calvinist ascetic ethos of the puritan when it was formalised into capitalist entrepreneurship (see Weber 1986: 163-206). But in relation to the Anglo-Saxon academic lawyer, one could claim that the primary juridical affiliation of the continental legal academic is not the adjudicator or the practitioner but the legislator.

If we consider the "crafty" university jurist allegedly representing AngloSaxon law, the situation seems quite different. She is primarily seen as an educator. Under the perceived or real pressures imposed by the professional bodies and their educational representatives, the significance of vocational preparation in law schools has been optimised at the expense of what was once called a "liberal legal education" which is the closest English equivalent to a Humboldtian university ideal. Correspondingly, her research is seldom expected to be more than textbooks and legal manuals, her primary affiliations are thought to be with the legal practice rather than the interdisciplinary university, the education she provides at 
university centres on vocational skills, and so on. Already Weber had noted a similar tension between two different approaches in higher education:

Behind all present discussions concerning the basic principles of the educational system, the struggle of the "professional man" type against the old "cultivated humanity" has acquired a decisive role in the irresistibly expanding bureaucratization of all public and private relations of authority and the ever-increasing significance of professional knowledge. And this struggle involves even the most intimate cultural questions (Weber 1947b: 677).

\section{Elective affinities and choices}

When Weber describes the idiosyncrasies of English legal education and Anglo-Saxon legal thinking, his verstehende or interpretative sociology includes a blind-spot that Weber himself seems to be aware of but is unable to address. Weber's sociology is namely itself a product of the society that it primarily describes. All his historical and comparative excursuses are, in the end, attempts to bring meaning to one particular form of society, that is, modern European capitalism and more specifically its continental market-capitalist variant. In so doing, Weber applies the formally rational categories that he claims to be unique to that society even to phenomena that are not intrinsically either formal or rational. Weber will, for example, always see emotiveness as an opposite of reason, the religious as an opposite of the secular, the private as an opposite of the public, and so on. But what he is unable to grasp is a society where such rationally constructed opposites are senseless. An educated British Muslim may, for example, understand the sacrifices that she must make in order to comply with the restrictions to autonomous self-expression as they are conveyed in the Sharia law, but for a rice-farmer in Indonesia totally immersed in her Islamic world-view the whole question about autonomous self-expression may appear as senseless. So Weber's excursuses will often 
function merely as the contrasting background against which modern European capitalism and its peculiar type of rationality are set.

Consequently Weber's rational and scientific world-view that may well accurately depict the self-understanding of the continental variant of modern market capitalism colonises everything that it describes and is consequently unable to understand an external object of research in Weber's own meaning, that is, as a structurally adequate and heuristic description of the meanings that social actors attach to their own actions. Weber may well be accused of "colonising" the common law in a similar way. His is an external continental account of the rationality - or the lack thereof - of Anglo-Saxon legal thinking, and as such, one could claim that it does not represent a true "understanding" of the phenomenon itself.

In addition to Weber's own methodological limitations, this essay has stretched the confines of its own approach beyond what many would recognise as an authentically Weberian perspective on law and society. By comparing how different arrangements in legal education have contributed to specific forms of legal thinking in England and on the continent, this essay has tried to infer the unique characteristics of one particular social actor that Weber perhaps implies but never explicitly discusses: the legal academic. Like Weber's own descriptive categories in general, the legal academic can only be an ideal type of a position that is possible for the university jurist but that does not appear as such in the real world. The legal academic's counterpart, that is, the academic lawyer, may perhaps be best described as the representative of an Anglo-Saxon legal thinking, but in its pure form, this contrasting ideal type is just as rare in the real world as the legal academic. The Anglo-Saxon academic lawyer does, however, highlight the predicament of the contemporary university jurist who is ever more frequently reduced into a thematic variation of the legal practitioner. 
Moreover, by designating the legal academic as a possible position or, in other words, as relative to choice, the ideal type takes on a political and normative character that would be, if not impossible, at least problematic for Weber. The orthodoxies of established Weber scholarship would hardly allow for such conclusions. How can Weber, then, equipped with a seemingly inadequate method and facing an apparently irresolvable "England problem" contribute to our understanding of the law and the social world? And what possible insights can Weber offer us into the predicament of the university jurist?

According to the French phenomenologist Maurice Merleau-Ponty, the impasses that Weber is himself unable to address in a satisfactory way are, indeed, his very strength (see also Arnason 1993). For Merleau-Ponty, Weber's inconsistencies and deficiencies provide a way of understanding history through symbolic matrices where a fundamental choice such as, for example, a specific form of legal thinking makes a particular form of society possible through its affinities with other choices such as economy, education, religion and the state. Merleau-Ponty claims that Weber's notion of "elective affinity" (Wahlverwandtschaft) enables us to understand the historical event as something other than a mere concurrence of circumstances but without making it into an imminent historical necessity either. Weber namely claims that it is possible to assert something on the degree of elective affinity between concrete structural forms "as to whether and how strongly they mutually favour one another's continuance or, conversely, hinder or exclude one another, whether they are 'adequate' or 'inadequate' in relation to one another" (Weber 1947a: 183; see also Howe 1978). Merleau-Ponty clarifies this affinity through the notion of choice: 
... it is as though it were in contact with one another that these choices were together finally able to produce Western capitalism, and the essence of the system does not pre-exist their encounter. Pluralism that seemed to be an obstacle to any unified interpretation of history is now on the contrary proof of the solidarity of the economic order and the order of politics, the order of law, the order of morality or religion, as soon as the economic order is itself treated as the choice of a relation amongst men and with the world and takes its place in the logic of choice (MerleauPonty 1968: 49-50).

Later Merleau-Ponty develops these Weberian influences into the concept of institution. Criticising the emphasis on pure coincidence in a structuralist understanding of history (Lévi-Strauss), Merleau-Ponty notes:

Institution in the strong sense of the word is this symbolic matrix that opens up a field, a dimensional future that makes a common experience and a history as consciousness possible (Merleau-Ponty 2003: 45).

And further:

Thus what we mean by institution are those events in experience that endow it with durable dimensions in relation to which a whole series of other experiences will acquire meaning, will form an intelligible series or a history - or, further, these events which deposit in me a meaning, not just as a vestige or a residue, but as an appeal for a continuance, a demand for a future (Merleau-Ponty 2003: 124). 
Merleau-Ponty's engagement with Weber is twofold. On the one hand, he recognises in Weber's phenomenology a non-Hegelian philosophy of history that is neither systematic nor strives for absolute knowledge:

Historical understanding does not introduce a system of arbitrarily chosen categories but only presupposes the possibility that we have a past that is ours, that in our freedom we can recapture the work of many other freedoms, that we can clarify the choices of others with our own and ours with theirs, that we can rectify one by the other, and that we can finally arrive at the truth. There is no greater respect, no objectivity more profound, than this claim of going to the source from which all history emanates. History is not an external god, a hidden reason of which we only have to record the conclusions; it is the metaphysical fact that one and the same life, our own, is played out both within us and outside us, in our present and in our past, that the world is a system with several points of entry, or, as one might say, that we have fellow men (Merleau-Ponty 1955: 34-35).

But related to this, on a much more personal level, Merleau-Ponty identifies unreservedly with Weber's "militant, even suffering, heroic" liberalism (Merleau-Ponty 1955: 41). Merleau-Ponty is unwilling to accept the orthodoxy of French party-led communism that subjects knowledge to the demands of political practice, and even if his own solution remains inadequate, he reveres the way in which Weber obstinately refuses to surrender his scholarship to propaganda whatever the noble cause may be.

In much a similar vein, the early Raymond Aron argues that Weber's political position is born as a consequence of the conflicting interests that dominate his rationalised world, and perhaps controversially it is the 
passionate and lucid devotion of the charismatic leader that must address them:

The professional politician lives from politics, but also for it. He is not so much motivated by vulgar ambition but by an inner calling, a need to act, to influence the destiny of men and their culture.

Weber was aware that this was an idealisation of the "charismatic" leader. But this ideal type was less of a methodological tool and more an image of the leader that Weber himself would have liked to be: his politics was heroic rather than realist (Aron 1950: 130)

Aron does, however, find Weber the philosopher less contradictory than Weber the person. The heroism so essential in Weber's personal engagement does not fit easily into the reality of democratic politics, and Aron claims that while Weber may have had a well informed idea of what to do, he was unwilling to assume the position of power that would enable him to implement that idea:

In the end, Weber's politics expresses a requirement of lucidity and prefers truth over action, human values over simple efficacy. Theoretically he recognised the constraints of politics, but in practice he rejected them as soon as they threatened to devalue human dignity. He would only have accepted a position of leadership in order to elevate the masses to respect true values. And this is why he remained an academic (Aron 1950: 132).

Aron contrasts the Weberian as the politician of understanding (entendement) with the Marxist as the politician of reason (raison). The former preserves values such as freedom and social justice in continuously changing situations that follow one another in a more or less unstructured way. Finding her way without the help of final objectives, she must 
acknowledge the dualism of means and ends and of facts and values; for her, every new moment resets the challenges that she faces. By way of contrast, the politician of reason can to a certain degree rely of historical inevitability; the capitalist state will undoubtedly eventually wither away, and one would simply need to adopt the correct strategies and tactics in order to secure the result. But for Aron the two ideal types represent extreme positions neither of which is realisable as such:

One risks degenerating into resignation, the other into blindness; one becomes incapacitated because of its dependency on history, the other because it forgets it; one is wiser, the other more heroic. This also means that all politics is at the same time both one and the other. There is no momentary agency that is not determined by a remote concern, no confidant of Providence that does not watch out for unique opportunities. The qualities of prophet and empiricist should not be incompatible. Politics is simultaneously the art of irrevocable choice and long-term planning. The man of action, open to conjunctures, would aim at the goals that he has been assigned in a rigid way (Aron 1948: 331). ${ }^{5}$

When Weber approaches an historical and social phenomenon such as, for example, legal thinking on the continent and in England, his presentation of ideal types is for the most part a logical reconstruction of verifiable

5 Michaël Pollak argues that Aron irons out the internal contradictions in Weber in order to legitimise a political liberalism: "Where Weber would have encountered an irreducible struggle between ultimate values, this reading finds in the equilibrium of ideological forces a guarantee of pluralism. In this sense the human sciences become instruments of permanent social readjustment ..." (Pollak 1998: 202). 
historical data. Weber's neo-Kantian ethos emphasises the centrality of propositions constituted by a self-conscious subject of science and knowledge. For post-Kantians like Merleau-Ponty and Aron such logical reconstructions would be problematic because it is unthinkable that a selfconscious subject could exist externally in relation to the social world that is being observed and analysed. Subject and world are one, and any claim that the subject makes about its social world is also one in a series of never-ending attempts with which the subject tries to fix its position in that world.

Moreover, for Weber the historical phenomena that are being analysed would have to display some degree of uniformity in order to be able to produce meaning into the social world. The lack of uniformity is exactly why the "England problem" is a problem; Anglo-Saxon legal thinking is a seemingly inexplicable deviation from the alleged regularity of formal rationality in law. But Merleau-Ponty's symbolic matrices and institutions need not adhere to such uniformity. Indeed, contrasting dissimilar phenomena against each other may well produce an understanding that was not even intended in the original study. So, for example, the different ways in which legal thinking has developed on the continent and in England may give us an insight into the position of the university jurist and how that position differs from the one adopted by the practitioner.

For commentators like Trubek, Weber's "England problem" is, indeed, a problem because of the apparent causal discrepancy between formally rational legal thinking and capitalism. Although the rationality of AngloSaxon law is allegedly both quantitatively and qualitatively different, it did not prevent British capitalism from developing in historically speaking roughly comparable ways. One can take this argument even further. One could namely claim that British capitalism provided the historical blueprint for much of the economic development of the remainder of 
Europe. Weber's abilities of foresight may not have made accurate predictions possible, but at least on a logical level the "England problem" can remain problematic only on the assumption that British and continental "capitalisms" are still comparable.

Perhaps this comparability is easier to contest than one would initially think. While many continental European states especially in the north continued to remodel Weber's traditional market capitalism into the welfare state that roughly speaking represented the cultural bourgeoisie's ideological sense of social-democratic solidarity, Britain adopted much more readily the free-market ideology of venture capitalism and consolidated it in an alleged "special relationship" with the new world. Seen from this perspective, today's Britain, as affluent as it may seem, represents the unfinished welfare state crippled by the neo-liberal ethos of Thatcherism and New Labour. In this respect, the relative differences between law schools and university jurists in England and on the continent may make more sense. The function of the academic lawyer is to provide exploitable individual solutions for a relatively unregulated market whereas the legal academic specifically partakes in the regulation of the market.

\section{Tragic modernity}

But it's not as if Weber could unequivocally reinstate his champion to her rightful place, for his overall view of the options that are open to the legal academic are much more complex than one would presume. Towards the end of his essay Science as a Vocation, Weber elaborates on the fundamentally contradictory existence of the academic:

The destiny of our times is characterised by rationalisation and intellectualisation and, above all, by the disenchantment of the world; even the ultimate and most sublime of values have 
retreated from the domain of the public either into the transcendental realm of mystic life or into the fraternity of direct and personal relations amongst individual human beings. It is hardly a coincidence that our greatest art is intimate and not monumental, nor that it is today only within the most intimate of circles amongst individual human beings, in pianissimo, that something pulsates which in former times swept, as a prophetic pneuma, through the great communities like a firestorm welding them together. If we try to force and to "invent" monumentality in art, miserable monstrosities such as the many monuments of the last twenty years are produced. If one tries to intellectually construe new religions without a new and genuine prophecy, then something similar in an inner sense will follow, but with even worse effects. And, finally, prophecies from the academic podium will create only fanatical sects but never a genuine community (Weber 1985: 612).

Disenchantment is a recurring theme in Weber and concerns the secularised Calvinist-turned-entrepreneur just as much as it does the bureaucrat who has left behind her original ideals of social solidarity. The loss of the spiritual fabric that once gave meaning to a shared world is apparently the price that one must pay for the efficient governing of society, and this element of alienation clearly aligns Weber with the Marxist tradition. But quite unlike Marx, Weber is both unable and unwilling to provide guidance as to what needs to be done. As Aron and Merleau-Ponty have pointed out, Weber's radicalness has little to do with any specific solutions that the academic might offer for her troubled times. It is much more a question of distancing oneself from a Hegelian notion of historical inevitability and opening the academic up to the plethora of political choices. But these choices are a mixed blessing; there is no normative user's manual that could confidently advise the academic on 
what choices to make. Indeed, quite the contrary, Weber seems to imply that any such guidance can only lead to forced results and ultimately disaster.

David Trubek takes this argument even further suggesting that there is a parallel between Weber's ideas on the nature of the academic's vocation and Weber's analysis of law. In both, it seems, Weber asserts what Trubek calls a "tragic modernity", that is, a fateful and contradictory destiny that can only lead to an impasse:

In the area of legal theory, he [Weber] cut through the triumphant mode of this discourse to uncover its darker side and critiqued its social and moral pretensions. In the realm of epistemology, he demonstrated the inherent limits of positivism, thus undermining the claims of those who thought this form of thought could lead to human emancipation. But in both cases, he saw no alternative, no way to move beyond the dualisms of liberal thought. As a result, his thought exhibits contradictory impulses, and his ultimately tragic stance is ... one of despair (Trubek 1986: 593).

Anthony Kronman identifies a very similar internal contradiction in Weber's account of modern law as a tension between, on the one hand, the demystification of law, that is, the instrumental acknowledgement of law as a powerful tool for the social planning of a democratic society and, on the other, the gradual realisation that the ever-growing complexity of legal regulation estranges the layperson from democratic decision-making resulting in increasing dependency on a technically proficient professional elite (Kronman 1983: 170-175). Kronman need not, however, limit this contradiction of legal modernity to the layperson's experiences. We can easily imagine how excessive legislation and the "over-juridification" of social relations produce similar conflicting effects in the experiences of the 
university jurist. The instrumentalism that is implied in her formally rational legal thinking enhances a sense of mastery and control that the escalating complexity of the legal system, the resulting factual shortcomings in social planning and the dehumanisation of social relations continuously undermine. The modern legal academic remains trapped in the no-man's land where she must at once continue to believe in the superior efficiency of her unique rationality and yet come to terms, not only with the limitations of what it can achieve, but also with the undeniable harm that it imposes.

But just like Trubek, Kronman does not see this internal conflict necessarily as a flaw in Weber's understanding of law but, rather, as an expression of his ambivalent philosophical position to modernity in general. Kronman identifies two incompatible strains of critique in Weber of which the first is a cautiously Marxist position and the second Nietzschean. The first critique addresses the limitations of a formal understanding of freedom and equality implied in the type of rationality that the university jurist cherishes. Through contractual arrangements one can construct the legal relations of one's choice, and one is entitled to demand equal treatment before the law. But the ideals of freedom and equality can only be fully realised in particular material circumstances that go beyond the jurist's formalism. Such material considerations would require, for instance, a fair distribution of wealth and humane working conditions. These Marxist affiliations have been commented upon often enough, but it is Weber's second critique, radically incompatible with the first, that is of interest here. Kronman namely argues that Weber's Nietzschean aspiration to rehabilitate personal authority in the age of depersonified bureaucratic practices represents a radical challenge to both the first critique of modernity and to his scientific project as a whole: 
The egalitarian ideal on which the bureaucratic order rests is threatened by the appearance of a leader with courage and passion and a sense of responsibility. A true leader feels entitled, by virtue of his own extraordinary qualities, to call on his followers to make the sacrifices he believes they must; nothing could be further from the attitude of the bureaucratic official who seeks, so far as possible, to eliminate everything strictly personal from his dealings with peers and clients and to perform his duties in a spirit of studied passionlessness. The bureaucrat is devoted, above all else, to the principle that every citizen is equal before the law, regardless of the distinctive personal qualities he happens to possess: from the perspective of the ideal bureaucrat, qualities of this sort can never be a basis for the exercise of authority. A leader, on the other hand, is an extraordinary man who demands to be recognized as such and claims the right to rule others on the ground that he has both the passion and the courageous selfdiscipline required to lead them, in a responsible way, toward the goal he champions (Kronman 1983: 184).

Duncan Kennedy recognises in the internal contradiction a Schmittian "decisionist" element:

In science, it turns out that "creativity" is not reducible to bureaucratically determinable characteristics that govern the specialized subdomains of the modem university. It involves an agonistic, irrational, intuitive moment without which no amount of learning and technique can accomplish anything of note. In politics, there is a similar split: The state is reduced more and more to a bureaucracy administering a rule system according to LFR [logically formal rationality], but the politicians are engaged in "fighting" for power, and have to make decisions with big ethical 
implications using an ethical apparatus that is internally contradictory and so often leaves them just having to "decide" (Kennedy 2004: 1061-1062).

The modern legal academic's fate is, then, doubly tragic. Not only must she recognise the limitations of the law in delivering feasible solutions to social problems, but she must also concede to a more general limitedness that is inherent in her very existence as an academic if she wishes to stay within the constraints of her own project. There is a certain correspondence between this impasse and so-called postmodern accounts of the law. The Weberian cul de sac with its wealth of choices is coupled with a fundamental undecidability, that is, an impossibility of making anything more than an informed leap of faith when facing the dualisms of liberalism. If we consider Weber's own troubled personal history including depression and nervous breakdowns, such a cul de sac can certainly be depicted as despairing. But perhaps there is another way of seeing this.

In his highly influential treatise, Martti Koskenniemi depicts the impasse that the international lawyer, both academic and practising, faces as an irresolvable conflict between the apologetic stance of the disillusioned practitioner and the necessarily utopian undercurrent of her vocation. In many ways this is a rearticulation of Weber's position. Bureaucratic efficiency is essential if one wishes to promote well-being in society, but it comes at the price of dehumanisation, of being cut off from the core values and principles that motivated one's participation in the promotion of wellbeing in the first place. Similarly Koskenniemi's jurist struggles with the legal routines that she must by necessity engage with but, at the same time, she is required to resist the temptation of being inundated by the private fantasy that, nevertheless, feeds her everyday work with the necessary imaginative impetus. But where Weber's reaction to the impasse may be depicted as despairing, Koskenniemi's jurist revels in it. The uncertainty 
that arises from the impasse enables the jurist to reject the unfounded generalities of lawlike certainties and to re-establish herself as a social actor. But her normative position is, Koskenniemi continues, "in the small" or, as Weber would say, in pianissimo. For Koskenniemi, normativity in pianissimo is synonymous with the integrity of the jurist (Koskenniemi 2005: 554-555).

One is, however, entitled to ask whether normativity in pianissimo reduces the jurist's social agency to ad hoc pragmatism. Is it simply a question of unrelated and disparate individual choices made in order to promote piecemeal improvements? Koskenniemi denies this because the jurist's agency can never take place through an unreflective technique or method. In finding meaning to the tasks that she has set herself, the jurist must also engage with the prospects of what is possible. In doing so, she must by necessity venture beyond her own disciplinary limitations into, for example, history, social theory and politics. But surrendering to normativity in pianissimo does not mean abandoning the larger project. Its political commitment must, however, be redefined:

It is not a commitment which seeks to realize given principles or ready-made social arrangements. It aims to construct the whole as a structure of open political conflict and constant institutional revision. The whole will be seen as a system which enables, as far as possible, particularized solutions, aimed at realizing authentic commitment. But it gives no intrinsic weight to solutions, once adopted, and it is ready to make constant adjustments once this seems called for. It positively excludes imperialism and totalitarianism. Beyond that, however, it makes no pretention to offer principles of the good life which would be valid in a global way (Koskenniemi 2005: 556). 
It is this Nietzschean position revelling in the inevitable conflicts of law that the human sciences offer the university jurist. It allows her to withdraw from her confused loyalties with the practice and to put herself radically into question in her interdisciplinary academic environment. It enables her to retain her integrity as a jurist, her sense of purpose and commitment as a social actor working from the privileged vantage point that academia offers. It includes within itself a constituent moment, an inevitable openness to the possibilities of the world that is not and cannot be constituted or regulated in advance. And only by seizing the power that the constituent moment represents can she fully embrace her position as a legal academic.

Perhaps the crux of the legal academic's radical possibility can be summed up in a single claim: law is a human science.

\section{Bibliography}

Arnason, J .P. (1993) 'Merleau-Ponty and Max Weber: an Unfinished Dialogue', Thesis Eleven, No. 36: 82-98.

Aron, R. (1948) Introduction à la philosophie del'histoire: essai sur les limites de l'objectivité historique. 12e édition, Paris: Gallimard.

Aron, R. (1950) La sociologie allemande contemporaine. 2e édition, Paris: Presses Universitaires de France.

Baker, J .H. (2002) 'Roman Law at the Third University of England', Current Legal Problems, Vol. 55: 123-150. 
Dicey, A.V. (1883) Can English Law be taught at the Universities? An inaugural lecture delivered at All Souls College, 21st April, 1883, London: Macmillan \& Co.

Dickens, C. (1837) Sketches by Boz: Illustrative of Every-day Life, and Every-day People. The second series, London: J . Macrone.

Duxbury, N. (2005) 'English J urisprudence Between Austin and Hart', Virginia Law Review, Vol. 91, No. 1: 1-91.

Ewing, S. (1987) 'Formal J ustice and the Spirit of Capitalism: Max Weber's Sociology of Law', Law and Society Review, Vol. 21, No. 3: 487-512.

Howe, R.H. (1978) 'Max Weber's Elective Affinities: Sociology Within the Bounds of Pure Reason', The American J ournal of Sociology, Vol. 84, No. 2: 366-385.

von J hering, R. (1852) Geist des römischen Rechts auf den verschiedenen Stufen seiner Entwicklung, Leipzig: Breitkopf und Härtel.

Kantorowicz, H. (1906) Der Kampf um die Rechtswissenschaft, Heidelberg: C. Winter.

Kennedy, D. (2004) 'The Disenchantment of Logically Formal Legal Rationality, or Max Weber's Sociology in the Genealogy of the Contemporary Mode of Western Legal Thought', Hastings Law J ournal, Vol. 55, No. 5: 1031-1076.

Koskenniemi, M. (2005) From Apology to Utopia. The Structure of International Legal Argument. Reissue with a new epilogue, Cambridge: Cambridge University Press. 
Kronman, A.T. (1983) Max Weber, London: Edward Arnold.

Lévy-Bruhl, H. (1950) 'Science du Droit ou "J uristique"', Cahiers Internationaux de Sociologie, Vol. VIII: 123-139.

Maitland, F.W. (1901) English Law and the Renaissance (the Rede Lecture for 1901) with some Notes, Cambridge: Cambridge University Press.

Merleau-Ponty, M. (1955) Les aventures dela dialectique, Paris: Gallimard.

Merleau-Ponty, M. (1968) Résumés de cours: Collège de France, 19521960, Paris: Gallimard.

Merleau-Ponty, M. (2003) L'institution dans l'histoire personnelle et publique. Le problème de la passivité: le sommeil, l'inconscient, la mémoire. Notes de Cours au Collège de France (1954-1955), Paris: Belin.

Plucknett, T.F.T. (1939) 'The Relations between Roman Law and English Common Law down to the Sixteenth Century: A General Survey', University of Toronto Law J ournal, Vol. 3, No. 1: 24-50.

Pollak, M. (1998) 'La place de Max Weber dans le champ intellectuel français', Droit et Société, No. 9: 195-210.

Pollock, F. and F.W. Maitland (1898) The History of English Law before the Time of Edward I. 2nd Edition, Cambridge: Cambridge University Press. 
Prest, W. (1967) 'Legal Education of the Gentry at the Inns of Court, 15601640', Past \& Present, No. 38: 20-39.

Reimann, M. (1990) 'Nineteenth Century German Legal Science', Boston College Law Review, Vol. 31, No. 4: 837-897.

Ruggle, G. (1787) Ignoramus: comoedia, Londini: T. Paine et filium.

Thornhill, C. (2007) German Political Philosophy: The Metaphysics of Law, London: Routledge.

Trubek, D.M. (1972) 'Max Weber on Law and the Rise of Capitalism', Wisconsin Law Review, Vol. 1972, No. 3: 720-753.

Trubek, D.M. (1986) 'Max Weber's Tragic Modernism and the Study of Law in Society', Law \& Society Review, Vol. 20, No. 4: 573-598.

Tucker, E.F.J . (1977) 'Ruggle's Ignoramus and Humanistic Criticism of the Language of the Common Law', Renaissance Quarterly, Vol. 30, No. 3: 341-350.

Weber, M. (1947a) Wirtschaft und Gesellschaft. Grundriss der Sozialökonomik. III Abteilung. 1. Halbband. 3. Aufl., unveränderter Nachdruck der zweiten, vermehrten Auflage, Tübingen: J.C.B. Mohr/ Siebeck.

Weber, M. (1947b) Wirtschaft und Gesellschaft. Grundriss der Sozialökonomik. III Abteilung. 2. Halbband. 3. Aufl., unveränderter Nachdruck der zweiten, vermehrten Auflage, Tübingen: J .C.B. Mohr/ Siebeck. 
Weber, M. (1985) 'Wissenschaft als Beruf', pp. 582-613, in M. Weber, Gesammelte Aufsätze zur Wissenschaftslehre, Hrsg. von J ohannes Winckelmann. 6. Auflage, Tübingen: Mohr/ Siebek.

Weber, M. (1986) 'Die protestantische Ethik und der Geist des Kapitalismus', pp. 17-206, in M. Weber, Gesammelte Aufsätze zur Religionssoziologie. Band 1, Tübingen: Mohr/ Siebek.

Weber, M. (1988) 'Politik als Beruf', pp. 505-561, in M. Weber, Gesammelte politische Schriften, Hrsg. von J ohannes Winckelmann. 5. Auflage, Tübingen: Mohr/ Siebek.

Wieacker, F. (1995) A History of Private Law in Europe, with Particular Reference to Germany. Trans. T. Weir, Oxford University Press: Oxford/New York, NY. 